\title{
Spanish Colonial Period Bricks from Churches in Laguna, Philippines: A Preliminary Chemical Characterisation Using X-ray Diffraction, Energy Dispersive X-ray Fluorescence and Fourier Transform Infrared
}

\author{
Jan-Michael C. Cayme, ${ }^{1 *}$ Arturo F. Bermejo III, ${ }^{1}$ Chris Allen Earl T. Francia, ${ }^{1}$ \\ Aniano N. Asor Jr, ${ }^{1}$ and Eric T. Miranda ${ }^{2}$ \\ ${ }^{1}$ Chemistry Department, De La Salle University, 2401 Taft Avenue, Malate, \\ Manila, Metro Manila, 0922 Philippines \\ ${ }^{2}$ School of Chemical, Biological and Materials Engineering and Sciences, \\ Mapúa University, 658 Muralla Street, Intramuros, Manila, \\ Metro Manila, 1002 Philippines \\ *Corresponding author: jm.cayme@gmail.com
}

Published online: 25 August 2021

To cite this article: Cayme, J. C. et al. (2021). Spanish colonial period bricks from churches in Laguna, Philippines: A preliminary chemical characterisation using X-ray diffraction, energy dispersive X-ray fluorescence and Fourier transform infrared. J. Phys. Sci., 32(2), 105-124. https://doi. org/10.21315/jps2021.32.2.8

To link to this article: https://doi.org/10.21315/jps2021.32.2.8

\begin{abstract}
Spanish Colonial Period brick samples dating to the 19th century from the Municipalities of Liliw and Pagsanjan in Laguna, Philippines was investigated. These samples were obtained from two church structures, a church bell tower from Liliw and a church convent from Pagsanjan. Combined X-ray diffraction (XRD), energy dispersive $X$-ray fluorescence (EDXRF) and Fourier transform infrared (FTIR) spectroscopy allowed the determination of chemical elements and minerals attributed to clay and sand, such as montmorillonite, quartz, corundum, hematite and calcite. On the basis of these compositions, the possible kilning conditions employed to fire the bricks during manufacture was also proposed. MATLAB ${ }^{\mathrm{TM}}$ programme was utilised in this study to interpret the data from $X R D$ and FTIR to rationalise the overlapping peaks in the spectrum. Results show that both brick samples were made of clay material that is non-calcareous with low refractory. The firing was performed in an oxidising atmosphere or an open-air environment at an estimated temperature of between $650^{\circ} \mathrm{C}$ and $850^{\circ} \mathrm{C}$. This preliminary study provides a baseline chemical characterisation data of colonial period bricks in the Philippines which will be useful for future conservation and restoration work not only locally but also within the Southeast Asian region.
\end{abstract}

Keywords: Brick, XRD, EDXRF, FTIR, cultural heritage, Philippines 


\section{INTRODUCTION}

Brick masonry is one of the primary construction materials together with stone masonry that was extensively utilised since antiquity until the present times. In the context of the Southeast Asian region, this masonry type is a material of choice for building ancient temples, fortifications and other colonial period structures. ${ }^{1}$ Despite its rather simple way of preparation, wherein a dried mixture of clay, sand and water is subjected to firing (i.e., kilning) the final brick form is largely dictated by the availability of raw materials from the site of construction and influenced by specific brick manufacturing traditions. ${ }^{2}$ These variations make old brick materials roughly unique for a particular region and characterising it can be a challenge. To effectively define a proper conservation and restoration measures for these historical bricks, baseline chemical composition data is necessary.

The most important component of all bricks is the clay minerals which gives the material its natural plastic behaviour. This enables the clay to be moulded to the desired shape upon contact with water and eventually hardens when dried. The firing temperature is also crucial to the durability of the bricks due to the formation of different post firing minerals forming a network of sturdier crystal structures. ${ }^{3}$ As for the general composition, clay bricks have abundant amount of silica, alumina, calcium and iron. These are chemical elements that form part of the minerals in bricks such as kaolinites, smectites, feldspars, hematite, quartz and calcite. ${ }^{4-6}$

The use of chemical techniques in providing extensive information on historical bricks in Southeast Asia is not yet widespread. Elemental and mineralogical analysis to determine ancient masonry techniques employed in manufacturing various pre-colonial bricks ( 7 th to 15 th century $\mathrm{AD}$ ) were reported from the temples at Sambor Prei Kuk in Cambodia, Po Nagar and My Són in Vietnam, Bujang Valley archaeological sites in Malaysia and the Batujaya archaeological sites in Indonesia. ${ }^{7-12}$ Luminescence dating techniques are the focal point of old brick research in Thailand, applied to masonry constructions in the Wiang Kaen and Thung Tuk archaeological sites and the Songkhla City Wall. ${ }^{13-15}$ Furthermore, chemical analyses were utilised to effectively determine the compatibility of replacement bricks for the ancient temples from Bagan in Myanmar and Vat Phou in Lao People's Democratic Republic (PDR). ${ }^{16,17}$ In the Philippines, bricks produced during the Spanish Colonial Period obtained from a church in Ilocos Norte and church convents from Laguna and Camarines Sur were described chemically. ${ }^{1,18,19}$ Emphasis on the estimation of firing temperature was made for the brick sample in Camarines Sur. ${ }^{1}$ These accounts show that chemical properties are relevant in understanding the behaviour of historical structures and will benefit cultural heritage sites in the Southeast Asian region. 
Two brick samples from a church convent and a church bell tower dating to the late 19th century, Spanish Colonial Period, were characterised in detail on this study, including the nature of the clay composition and the possible firing temperature. Both church structures were established by the Order of Friars Minor (OFM) or the Franciscan Order in Laguna, Philippines. ${ }^{20-22}$ One of the samples used in this study is an extension of the characterisation of brick obtained from the facade of the old church convent in Pagsanjan, Laguna that the authors initially described in another journal. ${ }^{19}$ The previous publication compares the elemental composition of the Pagsanjan brick with another historical brick sample in Ilocos Norte. The differences in the elemental composition between these two samples provide direct scientific evidence of the clay variations depending on the raw material's location. A general mineralogical composition, pore microstructure and nature of the clay mineral's decomposition were also presented in this earlier study. ${ }^{19}$

The novelty of the current approach is to compare the Pagsanjan brick with another brick sample taken from the base of the old church bell tower in Liliw, Laguna, employing a combination of X-ray diffraction (XRD), energy dispersive X-ray fluorescence (EDXRF) and Fourier transform infrared (FTIR) spectroscopy. XRD is the standard technique in identifying the minerals in clay bricks due to its repeating and ordered crystal structure. ${ }^{23,24}$ During the firing process, either accomplished in an oxidising or reducing environment, the clay minerals will experience a series of thermal transformations. The final mineral structure formed is dictated by the type of original clay material, the presence of carbonate groups and the firing temperature ${ }^{25}$ For instance, dehydroxylation of clay minerals will begin at around $550^{\circ} \mathrm{C}$ (i.e., kaolinite) and $950^{\circ} \mathrm{C}$ (i.e., smectite, illite) and gradually disappears as the temperature is increased. It is followed by the conversion of the clay minerals to spinel for smectite and illite and to cristobalite for kaolinite, to name a few, until it reaches about $1,100^{\circ} \mathrm{C} .{ }^{26,27}$ At this high temperature, an amorphous glass phase will start to appear. Formation of calcium silicate crystalline phases at high temperatures is also favoured for clay raw materials containing calcium carbonate $\left(\mathrm{CaCO}_{3}\right)$. Furthermore, hematite, responsible for the typical red colour of bricks, is formed from firing at an oxidising environment. XRD can detect all these mineralogical changes formed from the different temperature and firing conditions, to estimate the original firing temperature. ${ }^{28}$ Results from the XRD are complemented by the EDXRF that can rapidly determine the total elemental composition and its amount. ${ }^{29,30}$ Specifically, EDXRF is effective in obtaining the amount of fluxes. These techniques are demonstrated in a Malaysian study that reports the original firing temperature of archaeological bricks excavated from different temple sites in the Bujang Valley. ${ }^{31-34}$ Since certain samples were found by XRD analysis to contain kaolinite, illite and montmorillonite, the firing temperature is assumed to be lower than $550^{\circ} \mathrm{C}$. In some bricks, quartz mainly predominates and mullite is 
present. This further suggests that the firing temperature is greater than $550^{\circ} \mathrm{C}$ and could be between $850^{\circ} \mathrm{C}$ to $1,000^{\circ} \mathrm{C}$. The XRF has also identified the major and the trace chemical elements in the brick samples, which is found to be analogous to the chemical composition of the surrounding clay material.

Another analytical tool typically used in brick composition studies is the FTIR which gives information on the clay material source and possible identity of temper. ${ }^{35,36}$ Reports on the use of FTIR have been made on 13th century bricks in a medieval monastery and hospice in Venice, showing the presence of calcite, quartz, feldspars and iron oxides. The occurrence of these minerals is confirmed through XRD. ${ }^{37}$ Thus, the XRD, EDXRF and FTIR techniques applied to this preliminary research work will provide a valuable database of the chemical composition of colonial period architecture in the Philippines that can also be applied to other colonial buildings in Southeast Asia.

\section{EXPERIMENTAL}

\subsection{Collection of Brick Samples}

Figure 1 shows the general location of the Municipalities of Liliw and Pagsanjan in the Province of Laguna where the Spanish Colonial Period church structures described in this study are found. These buildings are usually situated in the middle of the old town centre where the local community would eventually expand during colonial times. The two municipalities are located about $18.3 \mathrm{~km}$ away from each other and are separated by the town of Magdalena. The old brick (LLW) representing Liliw was acquired in 2016 at approximately $2 \mathrm{ft}$ relative to the base of the church bell tower (Figure 2a). For the Pagsanjan old brick sample (PGJ), it was obtained at the front wall portion of the church convent in 2012, as shown in Figure 2b. The PGJ brick used for this study was part of the collected samples from Pagsanjan described in a previous study by the authors. ${ }^{19}$

The two different brick samples (Figure 2, inset) were of irregular shape and loose fragments easily dislodged from the structure. Minimal sample amounts were obtained, which is enough to perform the XRD, EDXRF and FTIR tests described in this study. This approach will ensure that the historical authenticity of the old structures is maintained. A careful assessment of the sample's physical properties (i.e., colour, texture and position) guarantees that it is manufactured during the Colonial Period and not a modern-day replica. Sub-samples (approximately $8.0 \mathrm{~g}$ each) were obtained by dividing the brick samples into two and scraping using a cleaned chisel, the middle portion about $1 \mathrm{~cm}$ to $2 \mathrm{~cm}$ from the outer surface to avoid contamination from the surrounding material. 

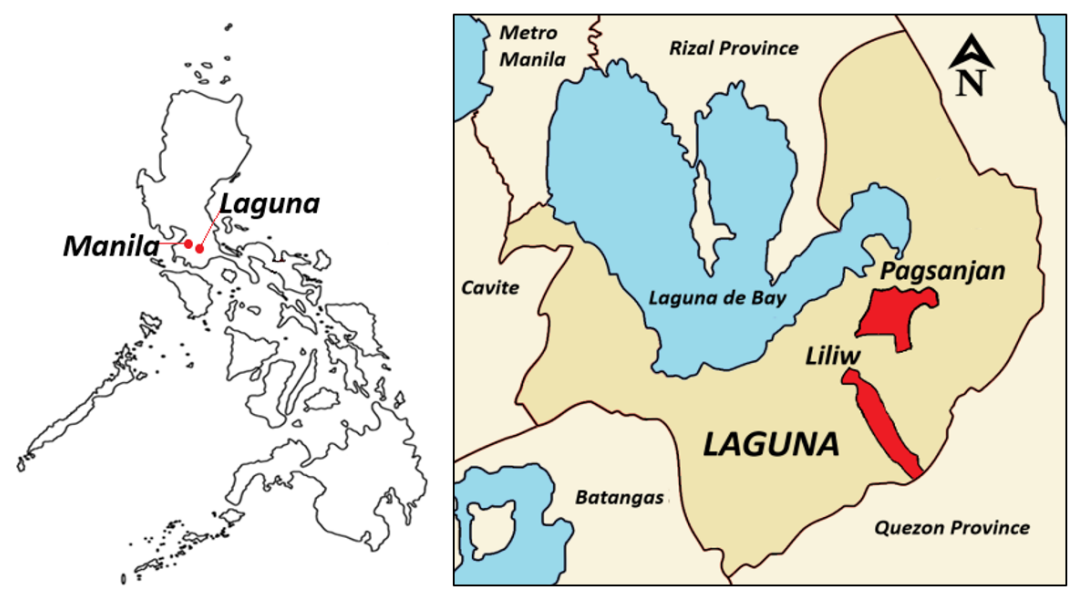

Figure 1: Map of the Philippines showing the Province of Laguna relative to the capital, Manila. The approximate locations of the Municipalities of Liliw and Pagsanjan are also shown.
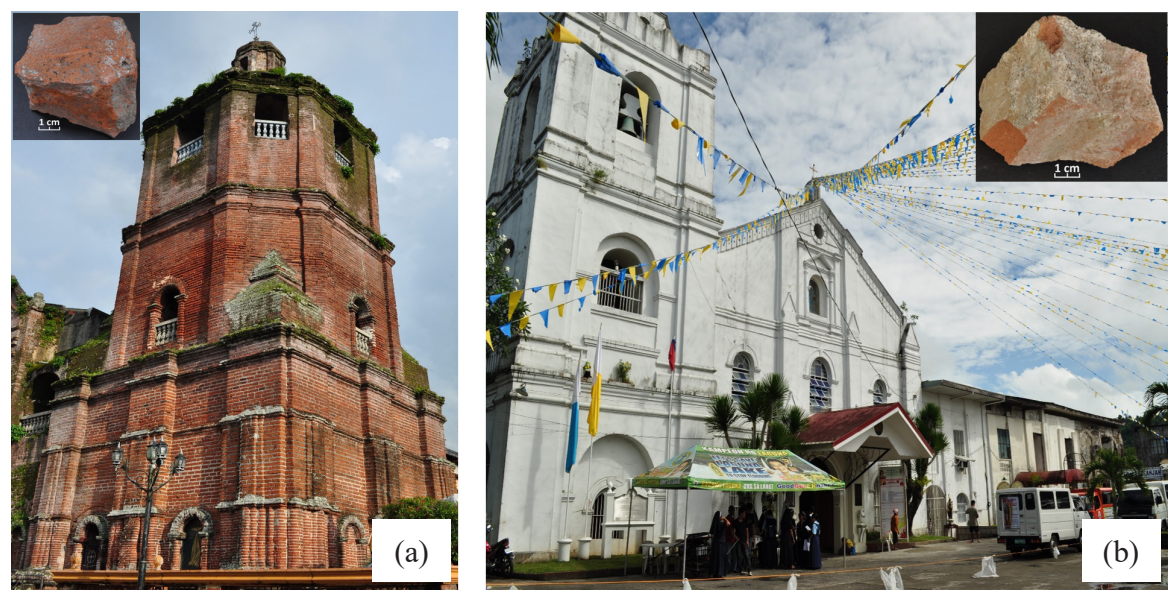

Figure 2: The 19th century Spanish Colonial Period Church structures described in this study; (a) Liliw church bell tower and (b) the Pagsanjan church convent (extreme right of the picture). Inset are the brick samples from these structures.

\subsection{Analysis by EDXRF}

The general elemental composition of the brick samples was examined using a Shimadzu EDX-7000, EDXRF spectrometer (Shimadzu Philippines Corporation, Metro Manila, Philippines). Small bulk portions of LLW and PGJ were placed individually on a polypropylene cup and the collimator was set to $3 \mathrm{~mm}$. The 
parameter chosen for this investigation was configured to a detailed analysis mode and performed in a vacuum atmosphere. ${ }^{1,38,39}$ This mode gave a total analysis time of almost 5 min per sample. Undetected elements described as loss on ignition (LOI) were adjusted relative to carbon dioxide $\left(\mathrm{CO}_{2}\right)$ due to the possible presence of carbonates or organic components embedded in the brick samples. The data was reported as percentage composition of elemental oxides for easy comparison with the XRD data.

\subsection{Analysis by FTIR Spectroscopy}

A qualitative mineral component analysis of LLW and PGJ were performed using a Thermo Scientific Nicolet 6700 FTIR Spectrometer (Thermo Electron Scientific Instruments Corporation, Wisconsin, USA). Brick sample portions of LLW and PGJ were grounded into fine powder and dried in an oven at $105^{\circ} \mathrm{C}$ for about $3 \mathrm{~h}$ prior to FTIR analysis. It was individually mixed with anhydrous potassium bromide $(\mathrm{KBr})$ powder, approximately 1:3 ratio and pressed together to form a pellet. The pressed pellet was scanned within the mid-infrared region $\left(4,000 \mathrm{~cm}^{-1}\right.$ to $\left.400 \mathrm{~cm}^{-1}\right)$ for 16 times at a resolution of $4 \mathrm{~cm}^{-1}$. The intensity of the FTIR peaks were processed from MATLAB ${ }^{\mathrm{TM}}$ programme (The MathWorks, Inc., Massachusetts, USA) for accuracy, with a prominence peak setting at 0.2 for minor peaks and 0.5 for relatively identifiable peaks. ${ }^{40}$ The identified peaks were compared to published mineral standard data for FTIR. ${ }^{18,41,42}$

\subsection{Analysis by XRD}

An Olympus TERRA-248 InXitu portable X-ray diffractometer (Olympus Corporation, Tokyo, Japan) was utilised for mineralogical characterisation of LLW and PGJ. The mineral phases were evaluated using cobalt $\left(\mathrm{Co}-\mathrm{K}_{\alpha}, \lambda=1.7903 \AA\right)$ as the source of X-ray target. Samples were homogenised and scanned continuously from a ${ }^{\circ} 2 \theta$ range of 3.00 to 55.00 . MATLAB ${ }^{\mathrm{TM}}$ programme was also used in graphing the XRD peaks and to determine the different mineral phases present in the samples. ${ }^{43,44}$ Prominent peaks in the XRD diffractogram were considered in obtaining the highest peaks for comparison with each other. ${ }^{40}$ The identity of the minerals present in LLW and PGJ were compared to reference minerals from the RRUFFTM Project (RRUF Project, Arizona, USA) database. ${ }^{45}$ 


\section{RESULTS AND DISCUSSION}

\subsection{Elemental Composition of Bricks Using EDXRF}

Since bricks are made from clay and sand, chemical elements pointing to this raw material origin should be detected by the EDXRF. Data shown in Table 1 indicate that silicate $\left(\mathrm{SiO}_{2}\right)$ and aluminates $\left(\mathrm{Al}_{2} \mathrm{O}_{3}\right)$ are the dominant element oxides found in LLW and PGJ. This is expected since sand is made largely of the mineral quartz $\left(\mathrm{SiO}_{2}\right)$ and depending on the purity, can contain the mineral feldspar which in turn is also a combination of mainly silicon and aluminium. Furthermore, clays consist of the plastic clay minerals or hydrous alumina phyllosilicates and naturally mixed sand minerals (non-plastic). All of these have the $\mathrm{SiO}_{2}$ and $\mathrm{Al}_{2} \mathrm{O}_{3}$ as part of its mineral structures. ${ }^{3}$

The presence of K-feldspar and Ca-feldspar minerals in both samples were supported by the occurrence of potassium oxide $\left(\mathrm{K}_{2} \mathrm{O}\right)$ and calcium oxide $(\mathrm{CaO})$. Potassium and calcium form part of the feldspar's endmembers. ${ }^{25}$ Possible 2:1 layered type clay mineral likely belonging to a smectite group (e.g., montmorillonite) is evident from the $\mathrm{SiO}_{2} / \mathrm{Al}_{2} \mathrm{O}_{3}$ ratio of 2.29 (LLW) and 1.95 (PGJ), which are typical values for this group. ${ }^{46,47}$ The amount of calcium for both LLW and PGJ also shows that the clay originated from a non-calcareous type of soil due to a percentage composition lower than $6.0 \%{ }^{48}$ These results are consistent with the reported $\mathrm{CaO}$ content for different clay deposits in Laguna Province, typically having average values of less than $1.0 \% \cdot{ }^{49,50}$ Calcium can affect the formation of certain type of minerals during the firing process and influences its vitrification, which in turn defines the durability of the brick material. ${ }^{51}$ Another information that can be obtained from the EDXRF data are the total amount of flux minerals in the samples represented by $\mathrm{K}_{2} \mathrm{O}$, iron (III) oxide $\left(\mathrm{Fe}_{2} \mathrm{O}_{3}\right), \mathrm{CaO}$, magnesium oxide $(\mathrm{MgO})$ and titanium dioxide $\left(\mathrm{TiO}_{2}\right)$. Getting the total percentage values gives a flux content of $13.22 \%$ for LLW and $14.79 \%$ for PGJ. Since the two samples exceed $9.0 \%$, both are considered as low refractory clays, wherein the amount of flux minerals is sufficient to induce vitrification at a lower firing temperature. ${ }^{52}$

The Laguna area is also known to have a geological feature that is abundant in ferromagnetic rocks. ${ }^{19}$ Maghemite, a family of iron oxides, is consistently identified from soil fractions in Laguna. ${ }^{53}$ The relatively high iron oxide content in the samples, at $7.517 \%$ and $11.557 \%$ for LLW and PGJ, supports the typical soil type in the province and is suitable for structural use. Furthermore, published data on the amount of iron oxides in clay deposits, specifically from the Municipality of Majayjay and the village of Botocan shows a high iron oxide content averaging $12.57 \% .^{50}$ The clay ridge found in Botocon extends to Pagsanjan and both of 
these places are within a $20 \mathrm{~km}$ distance from Liliw and Pagsanjan. Hence, this information is a good indicator of the iron oxide content of the samples and may further affirm that the bricks are sourced within the vicinity. The red colour of the bricks also suggests that iron-bearing hematite minerals are largely present in the sample and that the firing conditions were done in an oxidising (more air) environment. The high LOI values which is greater than $20 \%$ for both samples, may indicate the presence of carbonates, moisture and organic compounds in the raw clay material. ${ }^{25}$ It is not unusual that the brick would contain organic compounds because there are accounts that during the manufacturing process in the olden times, the clay mixture is mixed with residues from burned coconut husks to prevent cracking during the drying process. ${ }^{54}$

Table 1: EDXRF data of the brick samples.

\begin{tabular}{|c|c|c|}
\hline \multirow{2}{*}{ Metal oxides } & \multicolumn{2}{|c|}{ Percentage weight (\%) } \\
\hline & LLW & PGJ \\
\hline $\mathrm{SiO}_{2}$ & 39.514 & 39.308 \\
\hline $\mathrm{Al}_{2} \mathrm{O}_{3}$ & 17.262 & 20.204 \\
\hline $\mathrm{Fe}_{2} \mathrm{O}_{3}$ & 7.517 & 11.557 \\
\hline $\mathrm{CaO}$ & 3.953 & 1.481 \\
\hline $\mathrm{TiO}_{2}$ & 0.865 & 1.204 \\
\hline $\mathrm{K}_{2} \mathrm{O}$ & 0.885 & 0.548 \\
\hline $\mathrm{SO}_{3}$ & 0.244 & 0.618 \\
\hline $\mathrm{P}_{2} \mathrm{O}_{5}$ & 0.365 & 0.448 \\
\hline $\mathrm{MnO}$ & 0.171 & 0.297 \\
\hline $\mathrm{V}_{2} \mathrm{O}_{5}$ & 0.042 & 0.056 \\
\hline $\mathrm{ZnO}$ & 0.040 & 0.016 \\
\hline $\mathrm{SrO}$ & - & 0.012 \\
\hline $\mathrm{CuO}$ & 0.014 & - \\
\hline $\mathrm{PbO}$ & 0.001 & - \\
\hline LOI & 29.052 & 24.241 \\
\hline
\end{tabular}

Notes: $\mathrm{SO}_{3}$ (sulphur trioxide); $\mathrm{P}_{2} \mathrm{O}_{5}$ (phosphorus pentoxide); $\mathrm{MnO}$ (manganese oxide); $\mathrm{V}_{2} \mathrm{O}_{5}$ (vanadium pentoxide); $\mathrm{ZnO}$ (zinc oxide); $\mathrm{SrO}$ (strontium oxide); $\mathrm{CuO}$ (cupric oxide); $\mathrm{PbO}$ (lead monoxide).

\subsection{Qualitative Mineralogical Identification of Bricks Using FTIR}

Figure 3 shows the comparison of the FTIR spectra of LLW and PGJ analysed using MATLAB ${ }^{\mathrm{TM}}$ programme to identify the relevant absorption peaks. Silicates, aluminates, iron oxides and $\mathrm{CaO}$ are the major elemental units present in the brick sample based on the EDXRF data discussed in the previous section. Silicates in 


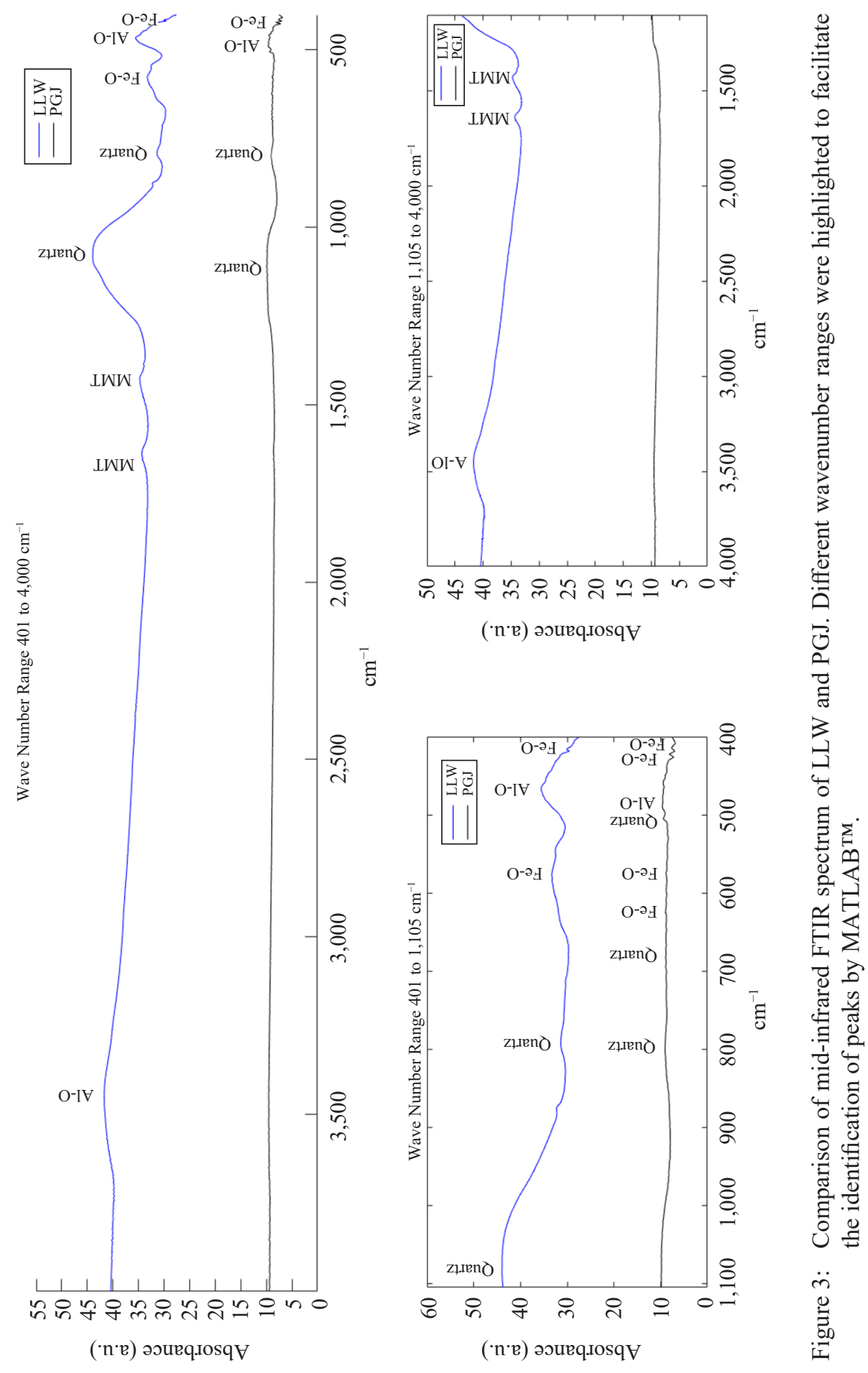


the form of quartz are readily identifiable by the characteristic bands from the range 1,200 to $400 \mathrm{~cm}^{-1}$. Specifically, the strong band at $1,082 \mathrm{~cm}^{-1}$ for LLW and $1,090 \mathrm{~cm}^{-1}$ for PGJ, are attributed to the Si-O asymmetrical stretching vibration (v3). These are complemented by the Si-O symmetrical stretching vibration (v1) at $793 \mathrm{~cm}^{-1}$ for LLW and $798 \mathrm{~cm}^{-1}$ for PGJ, respectively. Furthermore, the Si-O symmetrical bending vibration (v2) is detected in the PGJ sample at $683 \mathrm{~cm}^{-1}$ and a possible moiety of clay minerals or feldspars at $505 \mathrm{~cm}^{-1}$ assigned to the $\mathrm{Si}-\mathrm{O}-\mathrm{Al}$ stretch are also observed. ${ }^{1,19}$

The presence of clay minerals such as montmorillonite which was inferred from the $\mathrm{SiO}_{2} / \mathrm{Al}_{2} \mathrm{O}_{3}$ ratio in the EDXRF is also evident from the FTIR spectrum of both samples (Table 2). Montmorillonite is a 2:1 layered phyllosilicate belonging to the smectite group, where water and exchangeable ions are readily absorbed inbetween the clay layers causing it to swell. This property makes the clay material used in bricks to become plastic and easily moulded to the desired shape. The absorption peaks assigned to montmorillonite in the spectrum are the $\mathrm{OH}$ stretching and bending vibration modes. ${ }^{55}$ Clay fractions from Laguna have been reported in the literature to be dominated by montmorillonite based on XRD data. ${ }^{53}$ Thus, confirming this type of clay assignment. Bands for Al-O present in the structure of clay minerals are identified from the FTIR spectrum with the corresponding frequencies seen in Table 2. Iron oxide (Fe-O), which gives the distinctive red colour in the brick samples are also present. The aluminium in clay is replaced by iron as the firing temperature increases forming hematite $\left(\mathrm{Fe}_{2} \mathrm{O}_{3}\right)$ and magnetite (iron [II, III] oxide, $\mathrm{Fe}_{3} \mathrm{O}_{4}$ ). Characteristic absorption bands for $\mathrm{Fe}-\mathrm{O}$ are within the range predicted in the FTIR spectrum for LLW and PGJ.

Data from the FTIR can also give information on the possible lower firing temperature limit experienced by the brick samples during production. The formation of the relatively intense Si-O asymmetrical stretching bands (v3) for both samples is an outcome of an original clay raw material undergoing dehydroxylation and collapse of its aluminium octahedral sheet structure. This observation would usually happen as the firing temperature reaches $650{ }^{\circ} \mathrm{C} .{ }^{56}$ Furthermore, the formation of the post firing $\mathrm{Fe}-\mathrm{O}$ minerals will occur once the temperature of the kiln reaches more than $600^{\circ} \mathrm{C}$ and becomes stable at $700^{\circ} \mathrm{C} .{ }^{57}$ The absence of identifiable carbonate peaks in both spectra (Figure 3), possibly in the form of $\mathrm{CaCO}_{3}$, may suggest a maximum firing temperature of a little over than $800^{\circ} \mathrm{C}$. At this temperature, complete decomposition of carbonates is usually observed..$^{1,58}$ It is also likely that the absorbance for carbonates may be too low that major components like quartz and alumina may have overlapped with it. This will be confirmed further in the XRD results. The high refractory nature of both samples as seen from the EDXRF 
data can lower the vitrification temperature to about $50^{\circ} \mathrm{C} .{ }^{48} \mathrm{Hence}$, the LLW and PGJ may have been fired at a temperature range greater than $650^{\circ} \mathrm{C}$ to a little over than $800^{\circ} \mathrm{C}$.

Table 2: Summary of FTIR peak assignments for LLW and PGJ.

\begin{tabular}{lrr}
\hline \multirow{2}{*}{ Assignments $^{(\text {reference })}$} & \multicolumn{2}{c}{ Wavenumber $\left(\mathrm{cm}^{-1}\right)$} \\
\cline { 2 - 3 }${\text { Quartz }(S i-O))^{59}}^{2}$ & LLW & PGJ \\
& 1,082 & 505 \\
& & 683 \\
& & 798 \\
Montmorillonite $^{60}$ & 1,431 & 1,090 \\
& 1,637 & 1,460 \\
& 3,820 & 1,653 \\
Al-O $^{61}$ & 3,855 & 1,701 \\
& & \\
Fe-O $^{62}$ & 467 & 488 \\
& 3,454 & \\
& 417 & 415 \\
& 577 & 422 \\
& & 575 \\
& & 625 \\
\hline
\end{tabular}

\subsection{Mineral Identification Using XRD}

To identify the minerals present in LLW and PGJ samples, data from EDXRF (Table 1) was correlated with XRD to provide an initial assessment of the possible mineral composition. The major metal oxides (percentage weight $>1.0 \%$ ) identified from the EDXRF were considered. As a result, seven possible mineral candidates were examined: albite, corundum, calcite, montmorillonite, quartz, hematite and magnetite. Between the two iron-containing minerals (i.e., hematite and magnetite), hematite was assumed to be present in greater amounts in the samples due to the characteristic reddish colour and was not attracted to a magnet upon testing. Minerals contributing to the highest peaks in the XRD spectrum were determined by looking at the relative intensities $\left(I / I_{\max }\right.$, where $I$ is the intensity and $I_{\max }$ is the maximum intensity. This approach was used to determine which mineral dominates if more than one phase is attributed to a certain peak. Since overlapping peaks are common in XRD technique, computing the relative intensities will only enable the significant peaks to be analysed. Small intensity peaks were not considered in the analysis due to its low relative intensities. 
As seen from Figures 3 and 4, the XRD peaks of both samples are relatively similar, which further supports the outcome of the EDXRF and FTIR, suggesting that the clay supply may have originated in Laguna. There are reports of suitable quality clays available for ceramic manufacturing in Majayjay, near Liliw and Pagsanjan. ${ }^{49,50}$ A related XRD study of clay fractions from Laguna concludes that there is no significant difference in the clay composition of soil types in the eastern part of the province. ${ }^{53}$ Hence, the clay raw material may have been sourced within the immediate area. XRD analysis of the brick sample in this study shows that all six mineral candidates were present, except for magnetite, which was presumed to have negligible concentrations. Tables 3 and 4 summarise the relative intensities of these minerals for each sample.

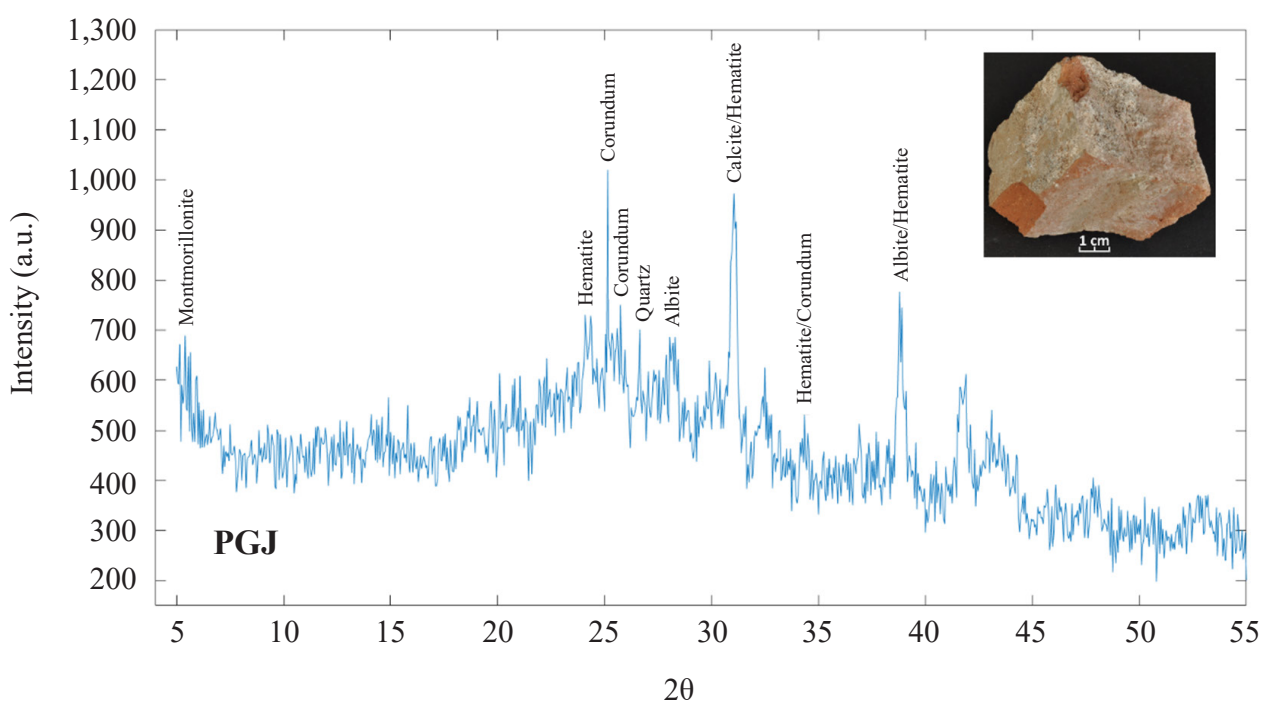

Figure 4: XRD peaks of PGJ showing some of the prominent major peaks.

For PGJ, the highest relative intensity of 1.00 comes from a $2 \theta$ of 25.15 (Table 3 ). This angle is identified to be from the mineral corundum, which is composed of aluminium oxide $\left(\mathrm{Al}_{2} \mathrm{O}_{3}\right)$. This assumption is expected since the relative intensity of corundum from the RRUFFTM database is 0.98 , which is also very high. The second-highest relative intensity (0.95) at $2 \theta$ of 31.05 is composed of overlapping peaks assigned to albite, calcite and hematite. Calcite and hematite, which are equal to 1 , have relative intensities that are highest at this diffraction angle. If these peaks have a subtractive cancellation effect, this might be why the diffraction angle has a lower relative intensity. As shown in Table 2, peaks for hematite are more dominant than calcite due to relative intensities present in different diffraction angles $(2 \theta)$. 


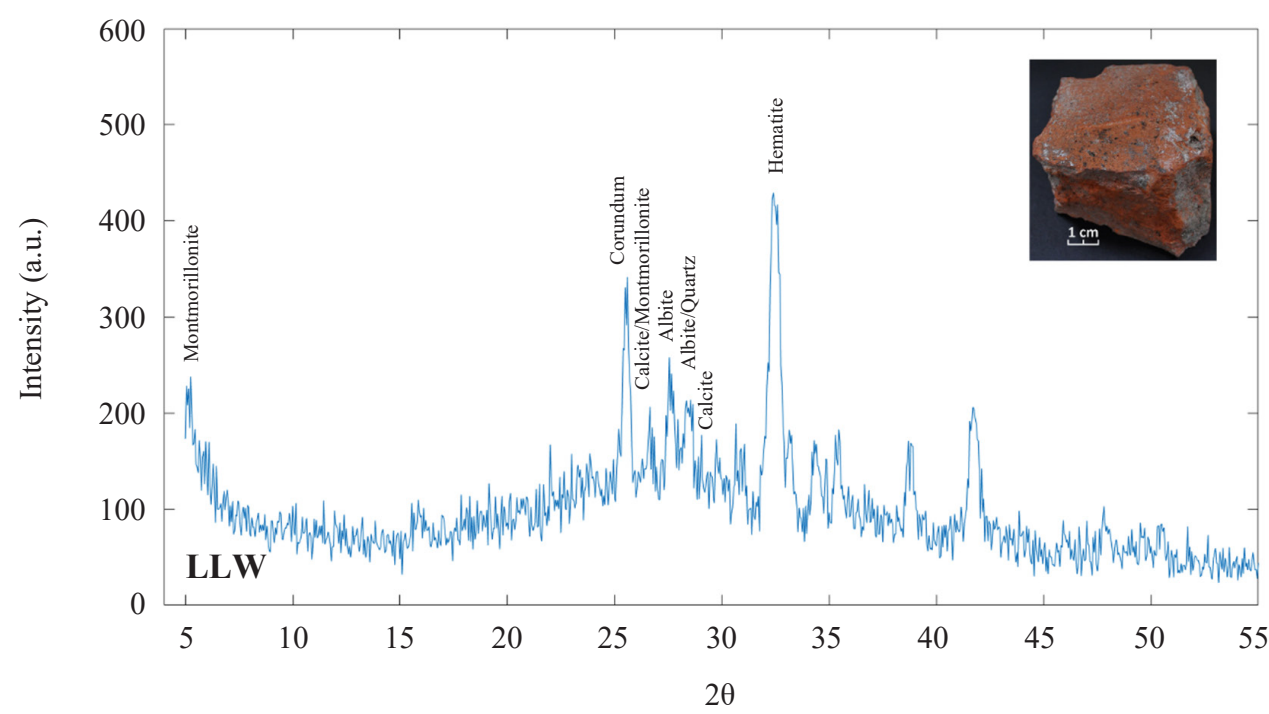

Figure 5: XRD peaks of LLW showing some of the prominent major peaks.

Furthermore, the contribution of calcite at 26.65 angle is low (0.13). This suggests that the composition of calcite is also low at both 26.65 and 31.05 diffraction angles. The remaining peaks for calcite have very low relative intensities and are not included in the table. Thus, the major contributor to the 31.05 diffraction angle comes from hematite. Peaks attributed to montmorillonite are highest in the lower diffraction angles. Since lower $2 \theta$ can only be attributed to montmorillonite, diffraction angles of 5.65 and 5.25 for PGJ and LLW, respectively, are assigned to this clay mineral. These assumptions are consistent with the reported XRD data values of montmorillonite obtained from soil samples containing clay in Laguna. ${ }^{53}$

For LLW, as shown in Table 4, the highest relative intensity of 1.00 came from a $2 \theta$ of 32.40 and was assigned to hematite, composed of iron oxide. This is followed by the $2 \theta$ of 25.60 , which has a relative intensity of 0.80 . This peak is assigned to corundum, which has a high relative intensity of 0.98 . Since these two intense XRD peaks are from hematite and corundum, it is assumed that high concentrations of these minerals are present in LLW. The composition of calcite is low due to a relative intensity peak of 0.41 at a 29.05 angle.

Even though the FTIR could not identify the presence of calcite (i.e., $\mathrm{CaCO}_{3}$ ), traces of this mineral were established in the samples using the XRD. The presence of low amounts of calcite together with the non-calcareous nature of LLW and PGJ indicates that it has not fully decomposed and the firing temperature did not exceed 
$850^{\circ} \mathrm{C}$. Furthermore, calcium silicates such as wollastonite usually appear at a temperature range of $850^{\circ} \mathrm{C}$ to $900^{\circ} \mathrm{C}$ and its absence in the XRD diffractogram of both samples implies that it did not meet the lowest temperature limit (i.e., $850^{\circ} \mathrm{C}$ ) during firing. ${ }^{63}$ The detection of the clay mineral montmorillonite also indicates that the original clay structure is still present in the samples, which can persist above $800^{\circ} \mathrm{C}$. The clay would eventually lose its characteristics and transform to a spinel-type mineral phase as the temperature increases (about $900^{\circ} \mathrm{C}$ ), which the XRD could not identify. ${ }^{64}$ Hence, indicating that LLW and PGJ may have been fired at a higher temperature limit between $800^{\circ} \mathrm{C}$ and $850^{\circ} \mathrm{C}$.

Table 3: Summary of major XRD peaks compared with relative intensities of individual minerals from PGJ.

\begin{tabular}{|c|c|c|c|c|c|c|c|c|}
\hline \multirow{2}{*}{$2 \theta$} & \multirow{2}{*}{$\begin{array}{l}\text { Intensity } \\
(I)\end{array}$} & \multirow{2}{*}{$\begin{array}{c}\text { Relative } \\
\text { intensity } \\
\left(I / I_{\max }\right)\end{array}$} & \multicolumn{6}{|c|}{ Relative intensities of minerals from XRD } \\
\hline & & & Albite & Corundum & Calcite & Montmorillonite & Quartz & Hematite \\
\hline 5.65 & 656 & 0.64 & & & & 1.00 & & \\
\hline 24.10 & 731 & 0.72 & & & & & & 0.45 \\
\hline 25.15 & 1,020 & 1.00 & & 0.98 & & & & \\
\hline 25.75 & 750 & 0.74 & & 0.54 & & & & \\
\hline 26.65 & 702 & 0.69 & & & 0.13 & 0.10 & 1.00 & \\
\hline 28.05 & 686 & 0.67 & 1.00 & & & & & \\
\hline 31.05 & 973 & 0.95 & 0.10 & & 1.00 & & & 1.00 \\
\hline 34.35 & 531 & 0.52 & & 1.00 & & & & 0.77 \\
\hline 38.80 & 777 & 0.76 & 0.10 & 0.40 & & & & 0.29 \\
\hline
\end{tabular}

Table 4: Summary of major XRD peaks compared with relative intensities of individual minerals from LLW.

\begin{tabular}{|c|c|c|c|c|c|c|c|c|}
\hline \multirow{2}{*}{$2 \theta$} & \multirow{2}{*}{$\begin{array}{c}\text { Intensity } \\
(I)\end{array}$} & \multirow{2}{*}{$\begin{array}{c}\text { Relative } \\
\text { intensity } \\
\left(I / I_{\max }\right)\end{array}$} & \multicolumn{6}{|c|}{ Relative intensities of minerals from XRD } \\
\hline & & & Albite & Corundum & Calcite & Montmorillonite & Quartz & Hematite \\
\hline 5.25 & 238 & 0.55 & & & & 1.00 & & \\
\hline 25.60 & 342 & 0.80 & & 0.98 & & & & \\
\hline 26.65 & 207 & 0.48 & & & 0.13 & 0.10 & 1.00 & \\
\hline 27.55 & 258 & 0.60 & 0.36 & & & & & \\
\hline 28.55 & 214 & 0.50 & 1.00 & & & & 0.28 & \\
\hline 29.05 & 177 & 0.41 & & & 1.00 & & & \\
\hline 32.40 & 429 & 1.00 & & & & & & 1.00 \\
\hline 35.45 & 183 & 0.43 & 0.10 & 1.00 & & 0.12 & 0.06 & 0.77 \\
\hline
\end{tabular}




\section{CONCLUSION}

The composition of 19th century brick samples from church structures in Laguna yielded significant amounts of quartz, montmorillonite clay, corundum and hematite. The presence of hematite suggests that the bricks were fired in an oxidising environment. Minor amounts of calcite are also present in both samples making the raw clay material non-calcareous. Based on the post-firing minerals formed and its low refractory nature, the firing temperature was determined to be within the range of $650^{\circ} \mathrm{C}$ to an upper limit of $800^{\circ} \mathrm{C}$ to $850^{\circ} \mathrm{C}$. This study also suggests that the manufacturing process of bricks from Liliw and Pagsanjan is almost similar and the raw materials used likely to originate within the Laguna Province.

The brick's sampling size should be increased for future studies to represent the variability in chemical composition within the same structure and in comparison, with different structures built within the same period. Furthermore, these studies should also trace the possible source of clay raw materials used to make the bricks and its relationship with the chemical composition of the actual brick sample. This method would enable a better understanding of the brick-making culture practiced by the local artisans of the past. Nevertheless, this preliminary study has emphasised the effectiveness of utilising chemical analysis in determining the possible raw material composition and the production method during the Spanish Colonial Period.

\section{ACKNOWLEDGEMENTS}

The authors are very grateful to the Municipalities of Liliw and Pagsanjan, Laguna and most specially to Rev. Fr. Noel Artillaga (Parish of Pagsanjan) and Rev. Fr. Marciano Dijan (Parish of Liliw) for the brick samples used in this study. The EDXRF data will not be possible without the equipment use of Shimadzu Philippines Corporation and Mr. Sean Dalawampu for his expertise on operating the EDXRF. The XRD data was provided by Cytek Solutions, Inc. and Ms. Lavinia Angeles who did the analysis is highly appreciated. The generous support of the Chemistry Department of the De La Salle University, Manila, is also highly appreciated. This study would not have been possible without the helpful insights and assistance of the following persons from the De La Salle University, Manila: Dr. Glenn Alea, Dr. Jaime Raul Janairo, Mr. Michael Ajero and Dr. Ma. Carmen Tan. 


\section{REFERENCES}

1. Cayme, J. M. (2021). Analytical chemistry methods of estimating the original firing temperature of bricks from a 19th century convent in the Philippine: Perspective of a Southeast Asian country. J. SPAFA., 5, 1-16. https://doi.org/10.26721/ spafajournal.2021.5.651

2. Jose Jr, R. T. (2003). Palitada: Skin of the church. In Zero in: Skin surface essence. Manila: Ateneo Art Gallery, Ayala Foundation, Inc., Eugenio Lopez Foundation, Inc. and Museum Pambata Foundation, Inc., 7-52.

3. Holtz, R. \& Kovacs, W. (1981). An introduction to geotechnical engineering. New Jersey: Prentice-Hall, Inc.

4. Cardiano, P. et al. (2004). Study and characterization of the ancient bricks of monastery of "San Filippo di Fragalà" in Franzzanò (Sicily). Anal. Chim. Acta., 519(1), 103-111. https://doi.org/10.1016/j.aca.2004.05.042

5. De Francesco, A. M. et al. (2009). Provenance and technology of bricks from the Greek colony of Kaulon (Calabria, Italy). Period. di Mineral., 78(3), 37-49. http://dx.doi.org/10.2451/2009PM0011

6. Taranto, M. et al. (2019). The bricks of Hagia Sophia (Istanbul, Turkey): A new hypothesis to explain their compositional difference. J. Cult. Herit., 38, 136-146. https://doi.org/10.1016/j.culher.2019.02.009

7. Shimoda, I., Uchida, E. \& Tsuda, K. (2019). Estimated construction order of the major shrines of Sambor Prei Kuk based on an analysis of bricks. Heritage, 2(3), 1941-1959. https://doi.org/10.3390/heritage2030118

8. Abdrakhimov, V. Z. \& Abdrakhimova, E. S. (2018). Chemical-elemental, phase compositions and porosity structure of ceramic samples from Cham Tower (Vietnam) more than 1000 y/o. Glass Ceram., 75, 154-159. https://doi.org/10 .1007/s10717-018-0046-1

9. Binda, L., Taranto, P. \& Condoleo, P. (2009). Difficulties in the design for conservation of archaeological remains: The G1 temple in the My Són. In C. A. Brebbia (Ed.). Structural studies, repairs and maintenance of heritage architecture XI. Series: WIT transactions on the built environment. Southampton, UK: WIT Press, 3-14. https://doi.org/10.2495/STR090011

10. Ramli, Z. et al. (2011). Scientific analysis of ancient bricks at Bukit Pendiat Temple (Site 17) and Pengkalan Bujang Temple (Site 23): A comparative study. Res. J. Appl. Sci., 6(7), 473-478. https://doi.org/10.3923/rjasci.2011.473.478

11. Ramli, Z. et al. (2014). Usage of local raw material in the construction of Candi Pengkalan Bujang (Site 18), Bujang Valley, Kedah. Res. J. Appl. Sci. Eng. Technol., 7(9), 1779-1786. https://doi.org/10.19026/rjaset.7.462

12. Ali, M. S. M., Ramli, Z. \& Utomo, B. B. (2014). Compositional analysis of ancient bricks from the Seg-II temple (Unur Lempeng), Batujaya, Indonesia. Paper presented at the 7th International Seminar on Ecology, Human Habitat and Environmental Change in the Malay World, Pekanbaru, Riau, Indonesia, 19-20 August. 
13. Won-in, K. et al. (2008). Preliminary study of the age of the Lanna period by thermoluminescence dating: A case study from the Wiang Kaen Ancient Site, Chiang Rai, Northern Thailand. Paper presented at the International Conference, Geoarchaeology and Archaeomineralogy, Sofia, Bulgaria, 29-30 October.

14. Pailoplee, S. et al. (2016). Thermoluminescence and optically stimulated luminescence dating of bricks from the Thung Tuk archaeological site, Southern Thailand. Songklanakarin J. Sci. Technol., 38(6), 699-705. https://doi.org/10 .14456/sjst-psu.2016.88

15. Puttagan, T. et al. (2019). Luminescence dating of brick constructions being part of Songkhla City Wall, Southern Thailand. Archaeol. Anthropol. Sci., 11, 53935403. https://doi.org/10.1007/s12520-019-00878-5

16. San, T. M., Kyaw, K. \& Kyaw, N. M. (2018). Physical, mechanical and chemical characterization on Ancient Brick Masonry of Monuments, Bagan, Myanmar. Int. J. Trend Sci. Res. Dev., 3(1), 875-881. https://doi.org/10.31142/ijtsrd19100

17. Manohar, S. et al. (2020). Characterization of historic bricks and binder at Vat Phou World Heritage Site in Lao PDR and the selection of compatible replacement units for restoration. Curr. Sci., 119(8), 1300-1307.

18. Cayme, J. M. \& Asor Jr, A. (2015). Extraction methods for quantifying iron, calcium and magnesium in a historic brickwork produced during the Spanish colonial period in the Philippines. KIMIKA, 26(1), 28-38. https://doi.org/10 .26534/kimika.v26i1.27-37

19. Cayme, J. M. et al. (2016). Chemical characterization of historical brickwork of the church convento in Pagsanjan, Laguna. KIMIKA, 27(1), 29-40. https://doi.org/10.26534/kimika.v27i1.29-40

20. De Huerta, F. (1887). Estado geografico, topografico, estadistico, historicoreligioso de la provincia apostolica de San Gregorio Magno. Manila: Binondo.

21. Klassen, W. (2010). Architecture in the Philippines: Filipino building in a crosscultural context (revised ed). Cebu City, Philippines: University of San Carlos Press.

22. Javellana, R. B. (2010). La Casa de Dios, the legacy of Filipino-Hispanic churches in the Philippines. Pasig, Philippines: Ortigas Foundation, Inc.

23. Petrénas, T. et al. (2012). A closer look at the ancient bricks of historical monuments: Essential step for the conservation of pottery. CHEMIJA, 23(3), 194-202.

24. Bunaciu, A. A., Udriştioiu, E. G. \& Aboul-Enein, H. Y. (2015). X-ray diffraction: Instrumentation and applications. Crit. Rev. Anal. Chem., 45(4), 289-299. https://doi.org/10.1080/10408347.2014.949616

25. Daghmehchi, M. et al. (2018). Mineralogical and thermal analyses of the Hellenistic ceramics from Laodicea Temple, Iran. Appl. Clay Sci., 162, 146-154. https://doi.org/10.1016/j.clay.2018.06.007

26. El Ouahabi, M. et al. (2015). Modified mineral phases during clay ceramic firing. Clays Clay Miner., 63, 404-413. https://doi.org/10.1346/CCMN.2015.0630506

27. Moropoulou, A., Bakolas, A. \& Bisbikou, K. (1995). Thermal analysis as a method of characterizing ancient ceramic technologies. Thermochim. Acta., 269/270, 743-753. https://doi.org/10.1016/0040-6031(95)02570-7 
28. Castellanos, O. M. A. et al. (2012). A comparative study of mineralogical transformations in fired clays from the Laboyos Valley, upper Magdalena basin (Colombia). Boletin Geol., 34, 43-55.

29. Ramli, Z. et al. (2013). X-ray diffraction and X-ray fluorescence of (9th-10th century AD) ancient bricks of Pengkalan Bujang Temple (Site 21/22) Bujang Valley, Kedah. Soc. Sci., 8(6), 500-504. https://doi.org/10.36478/sscience.2013 .500 .504

30. Johari, I. et al. (2010). Effect of the change of firing temperature on microstructure and physical properties of clay bricks from Beruas (Malaysia). Sci. Sinter., 42(2), 245-254. https://doi.org./10.2298/SOS1002245J

31. Ramli, Z. et al. (2012). Compositional analysis on ancient bricks from Candi Sungai Mas (Site 32/34), Bujang Valley, Kedah. Am. J. Appl. Sci., 9(2), 196-201. https://doi.org/10.3844/ajassp.2012.196.201

32. Ramli, Z. et al. (2013). Scientific studies of Candi Pengkalan Bujang (Site 19) ancient bricks: Knowledge of old Kedah community's in usage of local raw materials. Res. J. Appl. Sci. Eng. Technol., 6(15), 2859-2864. https://doi.org/10 $.19026 /$ rjaset.6.3796

33. Ramli, Z. \& Rahman, N. H. S. N. A. (2013). Compositional analysis of ancient bricks, Candi Bukit Kechil, Bujang Valley, Kedah. Res. J. App. Sci. Eng. Technol., 6(5), 924-930. https://doi.org/10.19026/rjaset.6.4143

34. Ramli, Z. et al. (2013). X-ray diffraction and X-ray fluorescence of ancient bricks of Candi Bukit Pendiat (Site 17), Bujang Valley, Kedah. Res. J. App. Sci. Eng. Technol., 6(6), 1094-1100. https://doi.org/10.19026/rjaset.6.4018

35. Nayak, P. S. \& Singh, B. K. (2007). Instrumental characterization of clay by XRF, XRD and FTIR. Bull. Mater. Sci., 30, 235-238. https://doi.org/10.1007/s12034 $-007-0042-5$

36. Amadori, M. L. et al. (2018). Advances in Achaemenid brick manufacturing technology: Evidence from the monumental gates at Tol-e Ajori (Fars, Iran). Appl. Clay Sci., 152, 131-142. https://doi.org/10.1016/j.clay.2017.11.004

37. Schiavon, N., Mazzocchin, G. A. \& Baudo, F. (2008). Chemical and mineralogical characterization of weathered historical bricks from the Venice lagoonal environment. Environ. Geol., 56, 767-775. https://doi.org/10.1007/s00254-008 $-1481-z$

38. Croffie, M. E. T. et al. (2020). Optimising sample preparation and calibrations in EDXRF for quantitative soil analysis. Agronomy, 10(9), 1309. https://doi.org/ 10.3390/agronomy10091309

39. Singh, V. \& Agrawal, H. (2012). Qualitative soil mineral analysis by EDXRF, XRD and AAS probes. Radiat. Phys. Chem., 81, 1796-1803. https://doi.org/10.1016/ j.radphyschem.2012.07.002

40. The MathWorks, Inc. (1994-2021). Findpeaks. Retrieved 23 December 2020 from https://www.mathworks.com/help/signal/ref/findpeaks.html

41. Derrick, M. R., Stulik, D. \& Landry, J. M. (1999). Infrared spectroscopy in conservation science: Scientific tools for conservation. Los Angeles: The Getty Conservation Institute. 
42. Schroeder, P. A. (2002). Infrared spectroscopy in clay science. In Rule, A. \& Gugenheim, S. (Eds.). CMS workshop lectures, Vol. 11, Teaching clay science. Aurora, CO: The Clay Mineral Society, 181-206.

43. Özkaya, Ö. A. \& Böke, H. (2009). Properties of Roman bricks and mortars used in Serapis temple in the city of Pergamon. Mater. Charact., 60(9), 995-1000. https://doi.org/10.1016/j.matchar.2009.04.003

44. Zhou, X. et al. (2018). XRD-based quantitative analysis of clay minerals using reference intensity ratios, mineral intensity factors, Rietveld and full pattern summation methods: A critical review. Solid Earth Sci., 3(1), 16-29. https://doi.org/10.1016/j.sesci.2017.12.002

45. Lafuente, B. et al. (2015). The power of databases: The RRUFF project. In Armbruster, T. \& Danisi, R. M. (Eds.). Highlights in mineralogical crystallography. Berlin, Germany: De Gruyter, 1-30.

46. Andrade, G. R. P. et al. (2018). Sequential mineral transformations from kaolinite to Fe-illite in two Brazilian mangrove soils. Geoderma., 309, 84-99. https://doi.org/10.1016/j.geoderma.2017.08.042

47. Khalifa, A. Z. et al. (2019). Comparing the reactivity of different natural clays under thermal and alkali activation. RILEM Tech. Lett., 4, 74-80. https://doi.org/10.21809/rilemtechlett.2019.85

48. Maniatis, Y. \& Tite, M. S. (1981). Technological examination of NeolithicBronze Age pottery from Central and Southeast Europe and from the Near East. J. Archaeol. Sci., 8(1), 59-76. https://doi.org/10.1016/0305-4403(81)90012-1

49. Cox, A. J. (1907). The occurrence, composition and radioactivity of the clays from Luzon, Philippine Islands. Philipp. J. Sci., 2(6), 413-438.

50. Cox, A. J. (1908). Laguna clays. Philipp. J. Sci., 3(5), 377-389.

51. Cultrone, G. et al. (2004). Influence of mineralogy and firing temperature on the porosity of bricks. J. Eur. Ceram. Soc., 24(3), 547-564. https://doi.org/10.1016/ S0955-2219(03)00249-8

52. Musthafa, A. M., Janaki, K. \& Velraj, G. (2010). Microscopy, porosimetry and chemical analysis to estimate the firing temperature if some archaeological pottery shreds from India. Microchem. J., 95(2), 311-314. https://doi.org/10.1016/j. microc.2010.01.006

53. Briones, A. A. (1963). Aggregate stability in relation to some physical and chemical properties of drained and reclaimed paddies. MSc diss., University of Hawaii.

54. Witt, J. C. (1916). Philippine paving-brick materials: A preliminary report. Philipp. J. Sci., 11(5), 203-221.

55. Müller, C. M. et al. (2014). Infrared attenuated total reflectance spectroscopy: An innovative strategy for analyzing mineral components in energy relevant systems. Sci. Rep., 4, 6764. https://doi.org/10.1038/srep06764

56. Venkatachalapathy, R. et al. (2002). Determination of firing temperature of ancient potteries by means of infrared and Mössbauer studies. Spectrosc. Lett., 35(6), 769-779. https://doi.org/10.1081/SL-120016279

57. Velraj, G. et al. (2009). Spectroscopic and porosimetry studies to estimate the firing temperature of some archaeological pottery shreds from India. Appl. Clay Sci., 43(3-4), 303-307. https://doi.org/10.1016/j.clay.2008.09.005 
58. Yanik, G. et al. (2012). The characterization of medieval ceramics excavated from the Eğirdir Caravanserai (Turkey). Ceram.-Silik., 56(3), 261-268.

59. RRUFF Project Database. n.d. Quartz R040031. Retrieved 22 January 2021 from https://rruff.info/quartz/display=default/R040031

60. Alekseeva, O. et al. (2019). Structural and thermal properties of montmorillonite/ ionic liquid composites. Mater., 12(16), 2578. https://doi.org/10.3390/ma12162578

61. Syed Aalam, C., Saravanan, C. G. \& Kannan, M. (2015). Experimental investigations on a CRDI system assisted diesel engine fueled with aluminum oxide nanoparticles blended biodiesel. Alex. Eng. J., 54(3), 351-358. https://doi. org/10.1016/j.aej.2015.04.009

62. Namduri, H. \& Nasrazadani, S. (2008). Quantitative analysis of iron oxides using Fourier transform infrared spectrophotometry. Corros. Sci., 50(9), 2493-2497. https://doi.org/10.1016/j.corsci.2008.06.034

63. Seetha, D. \& Velraj, G. (2016). Characterization and chemometric analysis of ancient pot shards trenched from Arpakkam, Tamil Nadu, India. J. Appl. Res. Technol., 14(5), 345-353. https://doi.org/10.1016/j.jart.2016.08.002

64. McConville, C. J. \& Lee, W. E. (2005). Microstructural development on firing illite and smectite clays compared with that in kaolinite. J. Am. Ceram. Soc., 88(8), 2267-2276. https://doi.org/10.1111/j.1551-2916.2005.00390.x 